\title{
Tracking triggering mechanisms for soft-sediment deformation structures in the Late Cretaceous Uberaba Formation, Bauru Basin, Brazil
}

\author{
Luciano Alessandretti 1* (D), Lucas Veríssimo Warren² (D), \\ Maurício Guerreiro Martinho dos Santos ${ }^{3}$ (D), Matheus Carvalho Virga' (D)
}

\begin{abstract}
Soft-sediment deformation (SSD) structures are widespread in the sedimentary record, and numerous triggering mechanisms can induce its development, including glaciation, earthquakes, overloading, ground-water fluctuations, and wave movement. The Late Cretaceous Uberaba Formation preserves SSD structures as small- and large-scale load casts and associated flame structures, pseudonodules, and convolute laminations observed in the contact of three well-defined intervals among fine- to coarse-grained lithic and conglomeratic sandstone with fine-grained arkose and mudstone beds. Based on the morphology of the SSD structures, sedimentary facies of the Uberaba Formation, and similarities with previous observations in the geological record and laboratory models, these features are assigned to liquefaction-fluidization processes as the major deformational mechanism triggered by seismic and aseismic agents. We propose that a deformation occurred just after the sedimentation triggered by seismic shock waves and overloading, induced by the sudden deposition of coarse-grained sandy debris on fine-grained sediments. Some of these structures can be classified as seismites, providing evidence of intraplate seismicity within the inner part of the South American Platform during the Late Cretaceous. This seismic activity is likely related to the uplift of the Alto Paranaíba High along reactivations of regional structures inherited from Proterozoic crustal discontinuities and coeval explosive magmatism of the MinasGoiás Alkaline Province.
\end{abstract}

KEYWORDS: Late Cretaceous; soft-sediment deformation structures; intraplate tectonism; seismicity; overloading; Bauru Basin.

\section{INTRODUCTION}

Soft-sediment deformation structures are conspicuous features found in both ancient and modern, shallowly buried, loose, and water saturated sediments (Allen 1982, Owen 1987). A wide range of natural triggers, including bioturbation, flooding, overloading, sudden oscillations of groundwater, slumping, storm waves, or seismic shaking (Lowe 1975, Allen 1986, Owen 1987, Shiki et al. 2000, van Loon 2009, Owen et al. 2011) can lead to the development of these structures. In the latter case, when liquefaction and/or fluidization are related to seismic activity, they can be designated as seismites (Seilacher 1969, 1984, 1991, Gibert et al. 2011, Moura-Lima et al. 2011, Rossetti et al. 2011). These earthquake-induced structures are of particular interest due to their implication for the tectonic history of sedimentary basins, including palaeoseismic studies and determination of tectonic reactivation cycles (Obermeier 1996, Moretti et al. 2014). However, identification

\footnotetext{
${ }^{1}$ Universidade Federal de Uberlândia - Uberlândia (MG), Brazil.

E-mail: luciano.geors@gmail.com, mathvirga@hotmail.com

${ }^{2}$ Universidade Estadual Paulista "Júlio de Mesquita Filho" - Rio Claro (SP), Brazil. E-mail: lucas.warren@unesp.br

${ }^{3}$ Universidade Federal do ABC - Santo André (SP), Brazil.

E-mail: santos.mauricio@ufabc.edu.br

${ }^{*}$ Corresponding author.
}

(c) 2020 The authors. This is an open access article distributed under the terms of the Creative Commons license. and interpretation of seismites can be a complex task, since non-seismic triggers can produce structures that resemble those produced by earthquakes (Rust 1968, Maltman et al. 2000, Van Rensbergen et al. 2003).

The Coniacian to Santonian Uberaba Formation of the Bauru Basin (Fig. 1) was interpreted as deposited under semiarid conditions in a large fluvial braided system (Batezelli and Ladeira 2016). Recent stratigraphic and sedimentological efforts conducted in the vicinities of the Uberaba city revealed that these sedimentary deposits contain several soft-sediment deformation structures concentrated, at least, along three deformed horizons. Considering the importance of these structures for the depositional, paleoseismic, and paleogeographic reconstruction of the Uberaba Formation, this contribution is focused on describing in detail the different types of soft-sediment deformations and discuss their driving force(s) and deformational and trigger(s) mechanisms. We also explore the geological evolution of alkaline provinces and structural uplifts that affected the Bauru Basin, aiming to associate tectonic and/or regional magmatic events with the intraplate tectonic activity.

\section{REGIONAL GEOLOGICAL CONTEXT}

The intracratonic Bauru Basin is located in central to southeastern Brazil and covers an area of approximately $370,000 \mathrm{~km}^{2}$ (Fig. 1). Its geological evolution is closely tied to the continental 
breakup of Gondwana and the opening of the South Atlantic Ocean during the Early Cretaceous (Maisey 2000, Batezelli and Ladeira 2016). Initial subsidence within the basin is related to the eruption of almost 1,700-meter-thick basaltic lavas of the Valanginian-Hauterivian Serra Geral Formation (Thiede and
Vasconcelos 2010). This massive volume of lavas putatively caused considerable thermal subsidence and lithospheric flexure rebound in the inner part of the South American Platform (Batezelli and Ladeira 2016), allowing the deposition of siliciclastic deposits of the Caiuá Group (Fig. 1). Menegazzo et al.
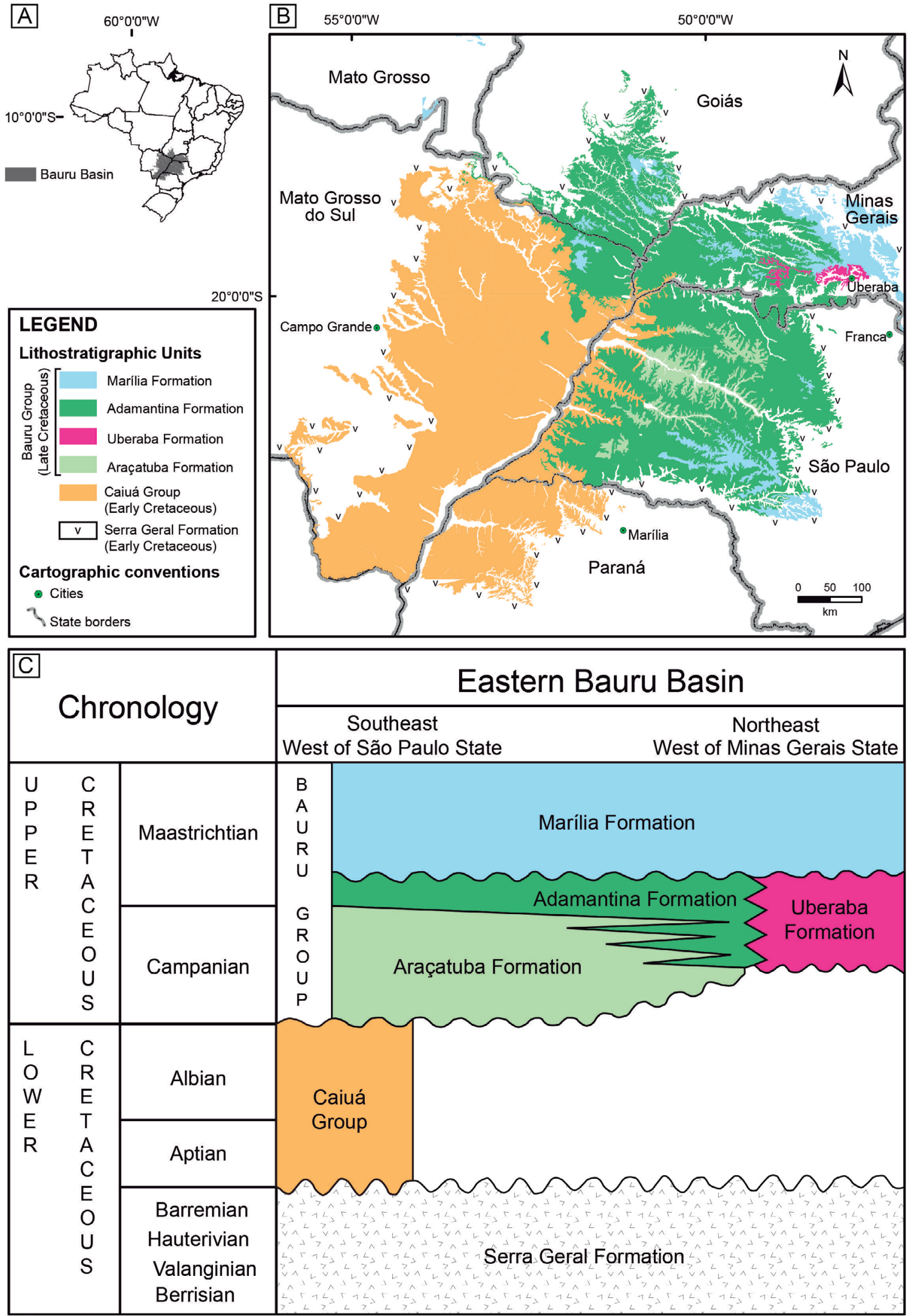

Figure 1. (A) Location of the Bauru Basin in Brazil. (B) Simplified geological map of the Cretaceous Bauru Basin. (C) Chronostratigraphic chart of the Bauru Basin in southeast Brazil. Modified from Batezelli and Ladeira (2016). 
(2016) proposed that the Bauru Basin is a component of a retroarc foreland system developed during the early stages of the Andean evolution. Sedimentation within the Bauru Basin would have been developed in the back-bulge province of this system (Menegazzo et al. 2016). The Turonian-Campanian uplift of the Alto Paranaíba High (Hasui et al. 1975) and associated alkaline intrusions attributed to the activity of the Trindade Mantle Plume (Gibson et al. 1995) (Fig. 2), promoted a pronounced mechanical subsidence pulse affecting the Bauru Basin. Correlated intrusions also occur in the southern part of the Goiás State, and are related to the coeval Goiás Alkaline Province (Junqueira-Brod et al. 2002).

Two active tectonic features delimited the northwestern and northeastern borders of the Bauru Basin during the Late Cretaceous: the Rondonópolis Anteclise (Coimbra and Fernandes 1995) and the Alto Paranaíba High (Hasui et al. 1975, Hasui and Haralyi 1991), respectively (Fig. 2). The Alto Paranaíba High is a Jurassic to Late Cretaceous positive tectonic structure developed from Neoproterozoic discontinuities related to the Brasília Fold Belt (Riccomini et al. 2005). The uplift of this structure is related to the activity of the Trindade (Gibson et al. 1995) or Tristan da Cunha (VanDecar et al. 1995) mantle plumes within the subcontinental lithospheric mantle. During the Cretaceous, the Alto Paranaíba High acted as a barrier between the Bauru and Sanfranciscana basins (Batezelli and Ladeira 2016). With $250 \mathrm{~km}$ in length and $70 \mathrm{~km}$ in width, this province comprises alkaline plutonic complexes, hypabyssal intrusions, lavas, and tuffs occurring along with an NW-SE fault system that acted as conduits for the potassic to ultrapotassic mafic to ultramafic magmatism (Almeida 1983, Gibson et al. 1995). The main faults reached great depths and were responsible for the upwelling for explosive alkaline magmatism that filled depressed areas generated by transtensional structures (Campos and Dardenne 1997). The associated volcanic rocks cover an area of approximately 4,500 $\mathrm{km}^{2}$ (Leonardos et al. 1991) and are assigned to the Mata da Corda Group of the Sanfranciscana Basin. The plutonic complexes vary between 2 and $6 \mathrm{~km}$ in diameter and are named as Tapira, Araxá, Salitre I and II, Serra Negra, and Catalão I and II (Fig. 2). Available K-Ar ages of the plutonic carbonatite complexes range between 79 and $97 \mathrm{Ma}$ (Amaral et al. 1967, Hasui and Cordani 1968, Sonoki and Garda 1988, Gomes et al. 1990). K-Ar radiometric dating performed on phlogopite crystals from the Mata da Corda Group provided an age of 83.6 $\pm 1.4 \mathrm{Ma}$ (Gibson et al. 1995), whereas Ar-Ar analyses of olivine phenocrysts of the Serra do Bueno kamafugite yielded an age of $90 \pm 4 \mathrm{Ma}$ (Gibson et al. 1994).

The Rondonópolis Anteclise is a positive tectonic feature with a NE-SW trend (Coimbra and Fernandes 1995) that was also tectonically active during the Late Cretaceous, with uplift along discontinuities related to the Neoproterozoic Brasiliano Cycle (Riccomini et al.2005). At that time, the Rondonópolis Anteclise acted as a barrier between the Bauru and Parecis basins (Coimbra and Fernandes 1995). Series of small pull-apart
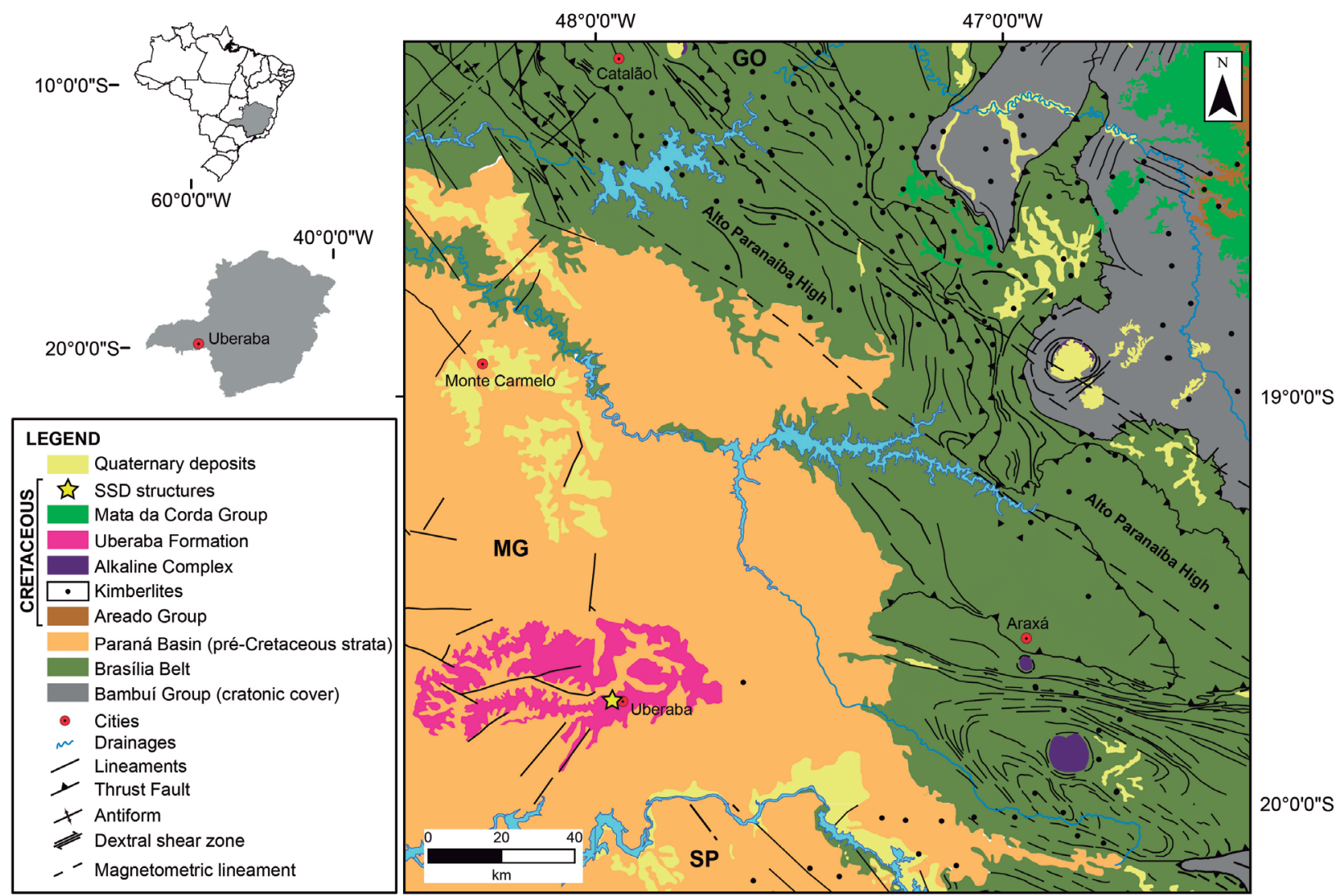

Source: adapted from Oliveira et al. (2004).

Figure 2. (A) Location of the study area in Brazil and State of Minas Gerais. (B) Simplified geological map of the Alto Paranaíba region showing locations of SSD structures of the Uberaba Formation, the distribution of the alkaline complexes and kimberlites in the Alto Paranaíba High, and the main tectonic features. 
basins formed within the anteclise due to transtensional reactivation of NE to ENE and NW-trending faults (Riccomini et al. 2005). Additionally, the anteclise was affected by the emplacement of voluminous mafic alkaline magmatism during the Late Cretaceous (Gibson et al. 1995, 1997). This magmatism is related to the impact of the Trindade Mantle Plume and present minimum and maximum ages of $83.4 \pm 2.4 \mathrm{Ma}$ (Ar-Ar in a dyke from the Poxoreu Igneous Province in Mato Grosso State, Gibson et al. 1995) and 97.1 $\pm 1.1 \mathrm{Ma}$, respectively ( $\mathrm{Rb}-\mathrm{Sr}$ in syenites and granites of the Ponta do Morro alkaline intrusion, Souza 1997).

\section{Geologic aspects of the Bauru Basin}

The Early to Late Cretaceous Bauru Basin is composed of two second-order sequences delimited by regional unconformities (Batezelli 2015), comprising:

- the lower sequence, corresponding to the Goio Erê, Rio Paraná, and Santo Anastácio formations (Caiuá Group in the meaning of Fernandes and Coimbra 1994);

- the upper sequence constituted by the Araçatuba, Adamantina/Uberaba and Marília formations (Bauru Group) (Fig. 1C).

The Early Cretaceous Caiuá Group rests unconformably over a regional erosive surface developed on the volcanic rocks of the Serra Geral Formation (Fernandes and Coimbra 2017). This unit has a total thickness of approximately $280 \mathrm{~m}$ and was deposited between the Aptian and Albian (Batezelli and Ladeira 2016). It is composed of fine-grained cross-bedded sandstone, organized in meter-thick beds interpreted as complex eolian dunes and sand sheet deposits from the Goio Erê, Rio Paraná, and Santo Anastácio formations (Fernandes and Coimbra 1994). The contact with the overlying Bauru Group is characterized by a regional unconformity (Batezelli 2015).

The Campanian to Maastrichtian Bauru Group is constituted by the Araçatuba, Adamantina, Uberaba, and Marília formations (Fig. 1), encompassing a succession of about $300 \mathrm{~m}$ of exclusively siliciclastic units (Batezelli and Ladeira 2016). The basal Araçatuba and Adamantina formations were interpreted as deposited over local depocenters developed directly on basalts of the Serra Geral Formation (Batezelli and Ladeira 2016). In the western part of the basin, these units occur over eolian deposits of the Caiuá Group. In general, the Araçatuba Formation is composed of very fine, red to greenish finegrained sandstone, siltstone, and shale (Basilici et al. 2016). Depending on their occurrence area, the Araçatuba Formation was interpreted as deposited in palustrine (Fernandes et al. 2003), lacustrine (Batezelli et al. 2016), or basinal evaporitic systems (Basilici et al. 2016). In the southern part of the Bauru Basin, the Adamantina Formation is composed of finegrained sandstones interpreted as deposited in mid to distal parts of a distributary fluvial system. In the northern part, this unit is constituted by fine-grained sandstone with subcritical climbing translatent strata interpreted as wind ripples in eolian sand sheets (Basilici and Dal'Bó 2010). The Marília Formation occur above the Uberaba Formation (detailed in the next topic) and is mainly constituted by fine sandstone, paleosoils, and conglomerates interpreted as deposited in alluvial system surrounded by a peripheral eolian sand sheet system (Batezelli et al. 2019).

\section{Geology of the Uberaba Formation}

The Uberaba Formation is exposed along the northeastern part of the Bauru Basin, mainly in the vicinities of the homonymous city. The succession is up to $70 \mathrm{~m}$ in thickness (Quintão et al.2017) and constitutes the basal part of the Bauru Group (Batezelli and Ladeira 2016), resting on erosional unconformity over the underlying Serra Geral Formation. This contact is characterized by the occurrence of a polymictic conglomerate composed of basalt, sandstone, and mudstone clasts (Hussak 1906, Fernandes and Coimbra 2017, Batezelli and Ladeira 2016). The upper contact of the Uberaba Formation with the Marilia Formation is abrupt and marked by the occurrence of a silexite bed and a quartz clasts-rich conglomerate cemented by calcite (Seer and Moraes 2017). A depositional age between 83.6 and $72.1 \mathrm{Ma}$ (Campanian) has been suggested for the Uberaba Formation based on remains of titanosaurid herbivorous dinosaurs (Huene 1939, Santucci and Bertini 2001) and lithostratigraphic correlations with Vale do Rio do Peixe and Marília formations. Lithologically, the unit is composed of fine- to medium-grained sandstone, conglomerate, pebbly sandstone, and siltstone facies (Fig. 3) deposited in a huge alluvial braided river system (Batezelli and Ladeira 2016).

Coeval explosive volcanic activity in the Alto Paranaíba region, related to the Patos Formation (Mata da Corda Group), produced large volumes of tephra, which was mechanically infiltrated in the intergranular pores of the sediments during
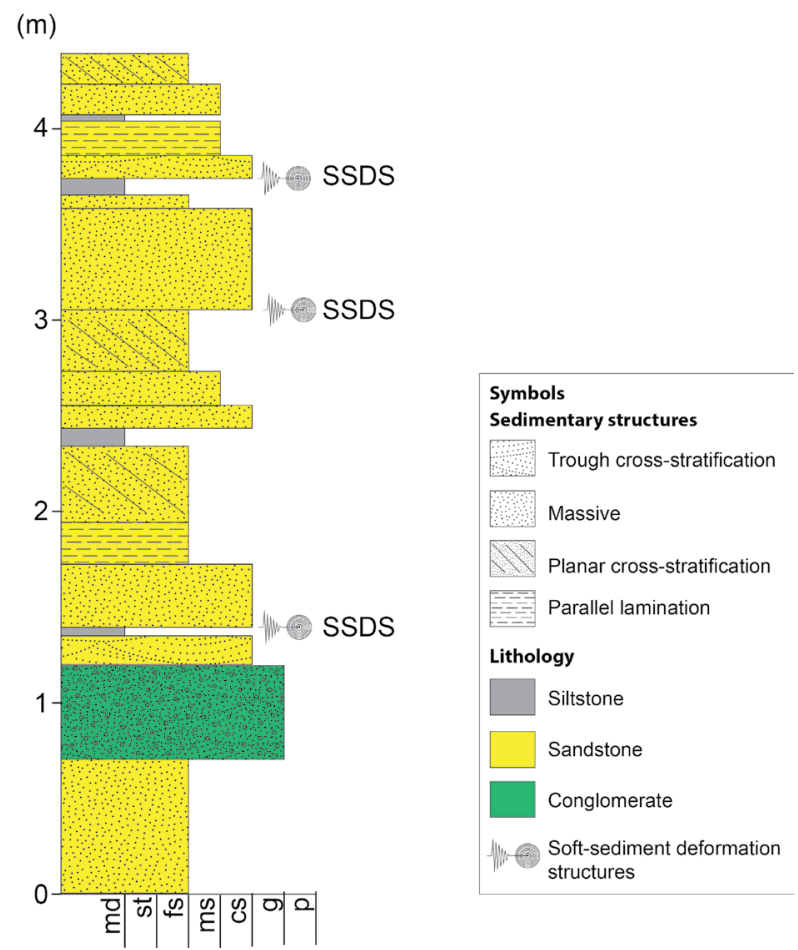

Figure 3. Simplified columnar section of the studied outcrop of the Uberaba Formation in the vicinities of the homonymous town along the MG-050 (coordinates: $187612 \mathrm{mE} / 7816707 \mathrm{mS}$ ). 
early diagenesis of the Uberaba Formation (Ferreira Jr. and Gomes 1999). In some cases, this volcanic clay matrix can reach up to $24.6 \%$ in the volume of the rock (Ferreira Jr. and Gomes 1999). According to Silva et al. (1994), Ferreira Jr. and Gomes (1999), and Quintão et al. (2017), the detrital components of the Uberaba Formation were also sourced from basalts of the Serra Geral Formation, quartzites, and schists of the Canastra, Ibiá and Araxá Groups, and intrusive rocks from the Minas-Goiás Alkaline Province. Exhumation of rocks from the Alto Paranaíba High started during the upper Lower Cretaceous to Upper Cretaceous (Costa and Sad 1968, Hasui 1968, Sad 1970, Riccomini et al. 2005), and probably provided the detrital components for the northeastern part of Bauru Basin (Ferreira Jr. and Gomes 1999, Quintão et al. 2017).

\section{SOFT SEDIMENT DEFORMATION STRUCTURES IN THE BAURU BASIN}

Despite previous descriptions of soft-sediment deformation structures in the Bauru Basin, all occurrences described in the literature are restricted to the lower sequence, correspondent to the Caiuá Group. The soft-sediment deformation (SSD) structures in the Caiuá Group was firstly reported by Suguio and Barcelos (1983), who described and interpreted boudinage features confined between undeformed sandstone beds of the Santo Anastácio Formation as earthquake-induced structures. Fernandes et al. (2007) reported two well-defined horizons characterized by large-scale deformations in eolian sandstone of the Early Cretaceous Rio Paraná Formation in the São Paulo and Mato Grosso do Sul States. These deformations comprise complex recumbent and convolute folds, clastic dikes, and pillar-like features, interpreted as a product of tectonic activity probably related to the emplacement of the Goiás Alkaline Province (Fernandes et al. 2007). Here, we describe and discuss for the first time SSD structures-bearing horizons in the Late Cretaceous Uberaba Formation of the Bauru Basin.

\section{Driving forces and deformational mechanisms}

Soft-sediment deformation structures develop in water-saturated, non-consolidated sediments, and prior to significant compaction (Mills 1983, Owen 1987, 1996). These structures are formed when a driving force, a deformation mechanism, and a trigger are collectively present (Owen et al.2011, Owen 1996), sediments lose grain-contact and are temporarily supported by intra-pore fluids (Allen 1982). In this way, such non-consolidated deposits lose internal friction and behave like a fluid, originating its characteristically ductile-like structures (Owen 1987). Different driving forces have been proposed to explain deformation in cohesionless sediments, comprising:

- gravity influence on slopes;

- uneven loading due to topographic irregularities in the sediment-water interface;

- variations in gravitational potential energy due to a reverse density gradient;

- shear by aqueous or other currents; and

- biological or chemical agents (Owen et al. 2011).
For cohesionless sediments (i.e., sandy deposits), the most important deformational mechanisms are liquefaction (loss of grains contacts and temporary transfer of grain weight to the pore fluid) (Allen 1982, Owen 1987, Owen and Moretti 2011) and fluidization (support of grain weight by the upward component of fluid drag) (Allen 1982, Nichols et al. 1994, Owen and Moretti 2011).

\section{MATERIAL AND METHODS}

The studied outcrop is a road cut along the MG-050 highway in the outskirts of Uberaba city, western region of the Minas Gerais State, SE Brazil. Facies description follows the proposal of Miall (1996) for fluvial deposits, with punctual adaptations. The classification of SSD structures was based on Alfaro et al. (1997), Owen (2003), and Moretti and Sabato (2007). The determination of the triggering mechanism(s) for soft-sediment deformation followed the proposal of Owen et al. (2011, and references therein).

\section{RESULTS}

\section{Sedimentary facies from the fluvial deposits of the Uberaba Formation}

The detailed outcrop corresponds to the intermediate part of the Uberaba Formation, well exposed in a road cut (BR 050), with about $300 \mathrm{~m}$ of lateral extension and $4 \mathrm{~m}$ of height. The metric tabular beds of the outcrop correspond to amalgamated lenticular and channelized decimeter scale of beds, commonly showing erosive base. The deposits are organized in metric scale thinning upward cycles characterized by massive and through-cross bedded very coarse to coarse sandstone facies at base grading to fine sandstone with parallel lamination, and culminating in mudstone facies at the top (Fig. 3). Despite the limited size of the studied section, the sedimentary facies described (see Tab. 1) and the architecture of the deposits, suggest deposition of longitudinal fluvial bars (Miall 2010), probably related to a huge alluvial braided river system (Batezelli and Ladeira 2016).

\section{Soft-sediment deformation structures in the Uberaba Formation}

A great variety of SSD structures is observed in the irregular interfaces between greenish, fine- to coarse-grained lithic sandstone, conglomeratic sandstone with red, fine-grained arkose and mudstone from the intermediate part of the Uberaba Formation. At least three distinct stratigraphic horizons with widespread SSD structures have been recognized in the study area (Figs. 4 to 7). It is possible to distinguish five types of SSD structures based on their morphology:

- small-scale load structures;

- large-scale load structures;

- pseudonodules;

- flame structures; and

- convolute lamination. 
Braz. J. Geol. (2020), 50(1): e20190100

Table 1. Description of sedimentary facies recognized in Uberaba Formation and interpretation of depositional processes.

\begin{tabular}{|c|c|c|c|}
\hline Code & Facies & Description & Depositional Process \\
\hline $\mathrm{Gm}$ & $\begin{array}{l}\text { Matrix-supported } \\
\text { massive conglomerate }\end{array}$ & $\begin{array}{l}\text { Decimeter to meter-scale lenticular beds of polimitic and matrix- } \\
\text { supported massive conglomerate. The clasts are mainly constituted } \\
\text { by basalt, alkaline rocks, and quartzite. The matrix is a secondary } \\
\text { element and is composed of medium to coarse sandstone }\end{array}$ & $\begin{array}{l}\text { Gravel bedforms } \\
\text { deposited in fluvial channels } \\
\text { by inertial bedflows }\end{array}$ \\
\hline St & $\begin{array}{l}\text { Through cross-bedded } \\
\text { sandstone }\end{array}$ & $\begin{array}{l}\text { Decimeter to meter-scale tabular and lenticular beds of medium } \\
\text { to very coarse through cross-bedded sandstone. Occasionally, } \\
\text { granules and thin conglomerate lens occur interbedded in } \\
\text { the lower part of the series of through cross-stratification. }\end{array}$ & $\begin{array}{l}\text { Migration of linguoid } \\
\text { 3D sand dunes under } \\
\text { unidirectional flows }\end{array}$ \\
\hline$S p$ & $\begin{array}{l}\text { Sandstone with planar } \\
\text { cross-stratification }\end{array}$ & $\begin{array}{l}\text { Decimeter to meter-scale tabular and lenticular beds } \\
\text { of sandstone with planar cross-stratification }\end{array}$ & $\begin{array}{l}\text { Migration of transverse } \\
\text { 2D sand dunes under } \\
\text { unidirectional flows }\end{array}$ \\
\hline Sh & $\begin{array}{l}\text { Sandstone with } \\
\text { parallel lamination }\end{array}$ & $\begin{array}{l}\text { Decimeter to meter-scale tabular beds of fine to } \\
\text { coarse sandstone with parallel lamination, sometimes } \\
\text { showing streaming lineation in the bedding }\end{array}$ & $\begin{array}{l}\text { Migration of low amplitude } \\
\text { bedforms formed under } \\
\text { upper flow regime in the top } \\
\text { of fluvial bars }\end{array}$ \\
\hline $\mathrm{Fm}$ & Massive silststone & $\begin{array}{l}\text { This facies include tabular beds, of massive siltstone } \\
\text { usually light to dark grey or yellow, occasionally with } \\
\text { centimetric poligonal dissecation cracks. The laminated } \\
\text { variety presents very fine sparse sand grains. }\end{array}$ & $\begin{array}{l}\text { Settling of siliciclastic } \\
\text { mud in calm water }\end{array}$ \\
\hline
\end{tabular}
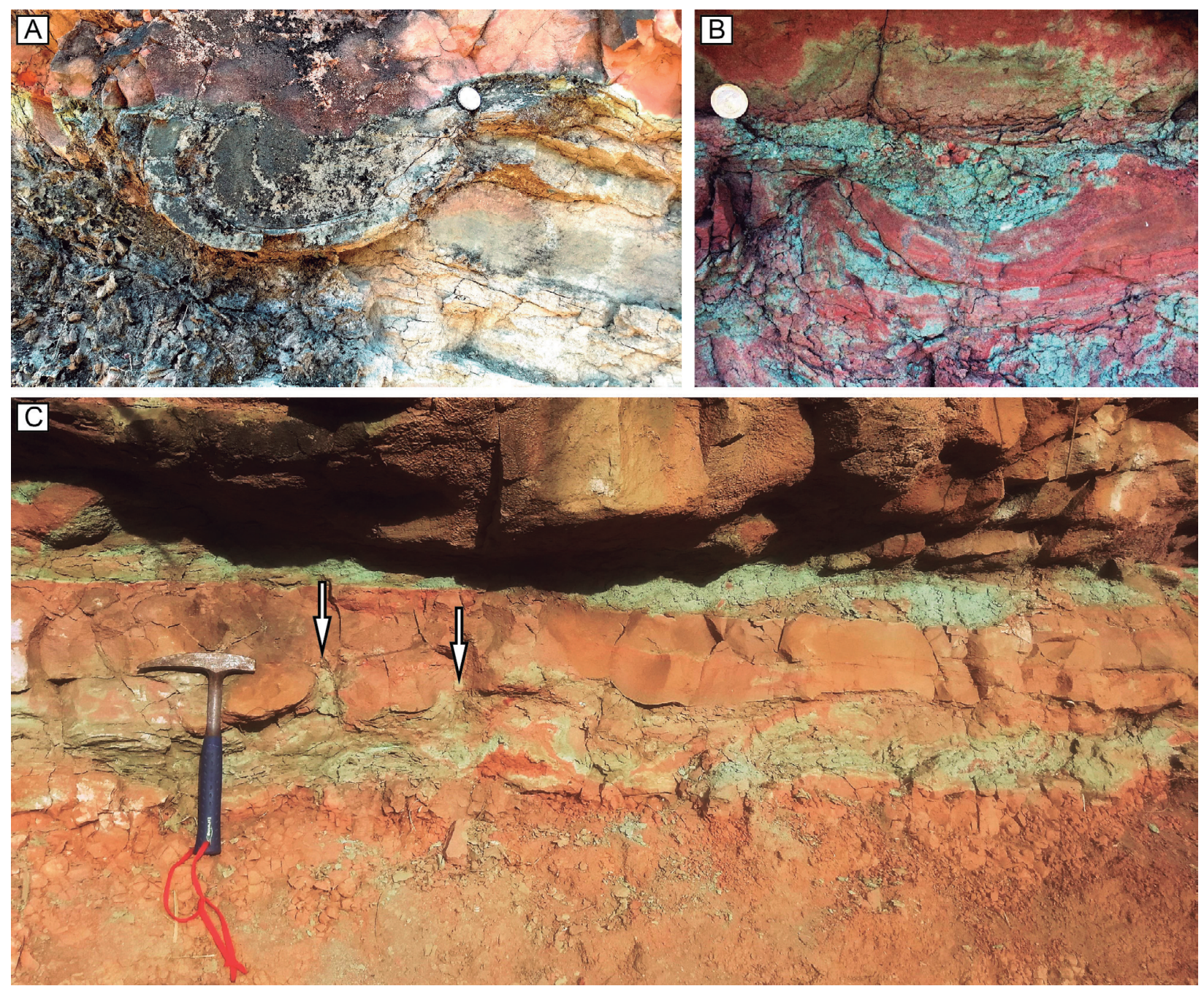

Figure 4. (A) Large-scale load structure formed by fine grained arkose overlying fine-grained lithic sandstone. Note the deformed internal lamination. (B) Large-scale load structure formed by medium- to coarse-grained lithic sandstone overlying fine-grained arkose. (C) Large-scale load casts composed of fine-grained arkose overlying coarse-grained lithic sandstone and associated with flame structures (black and white arrows). 

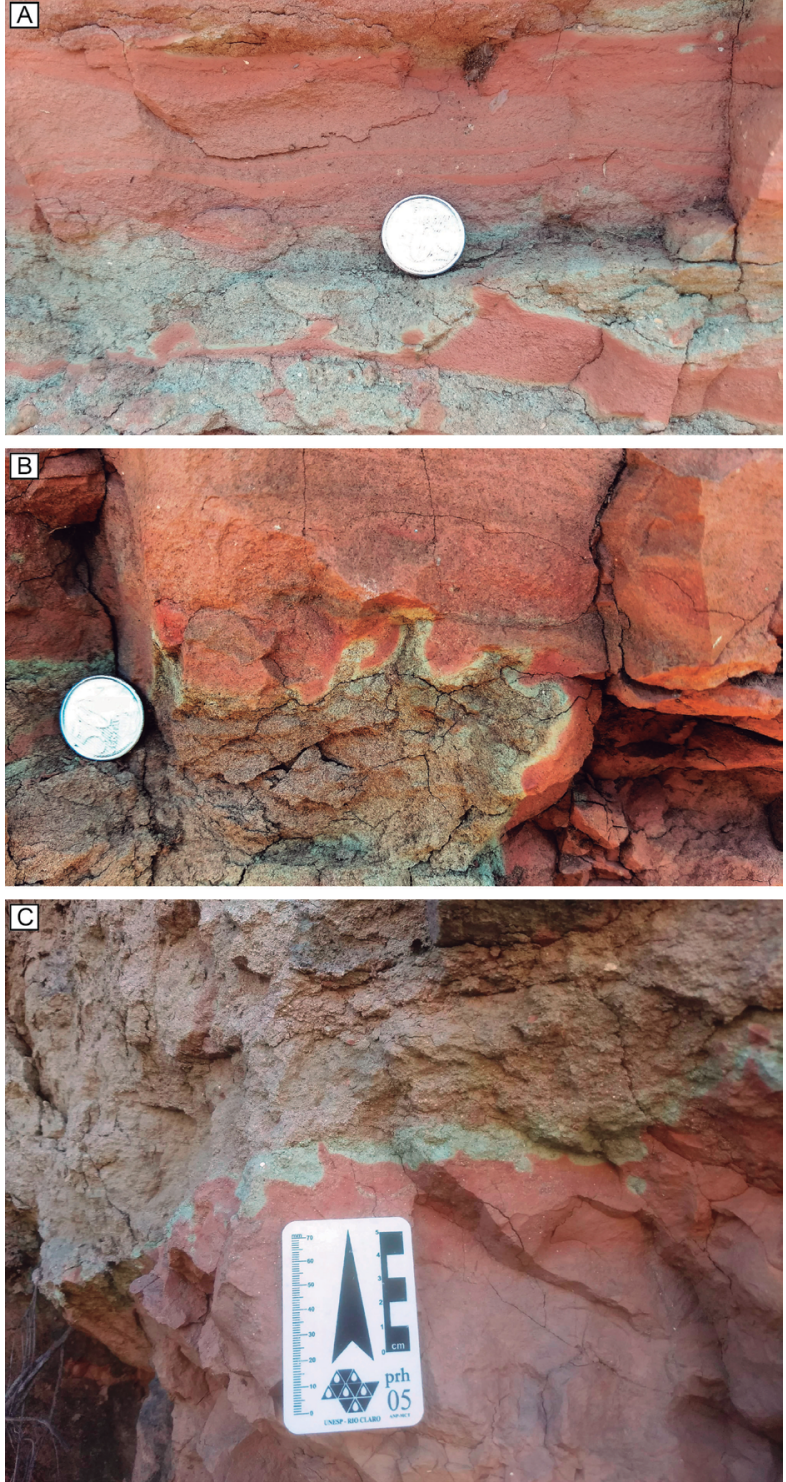

Figure 5. (A) Small-scale load structure composed of mediumgrained lithic sandstone overlying very-fine grained arkose and associated with flame structures. (B) Small-scale load structure formed by fine-grained arkose overlying fine-grained lithic sandstone and associated with flame structures. (C) A deformed surface bearing small-scale load structures composed by coarse-grained lithic sandstone overlying very-fine grained arkose and associated with flame structures. Note the difference in the texture of the two sandstone layers in B and C. The coin in A and B is $2.4 \mathrm{~cm}$ in diameter.
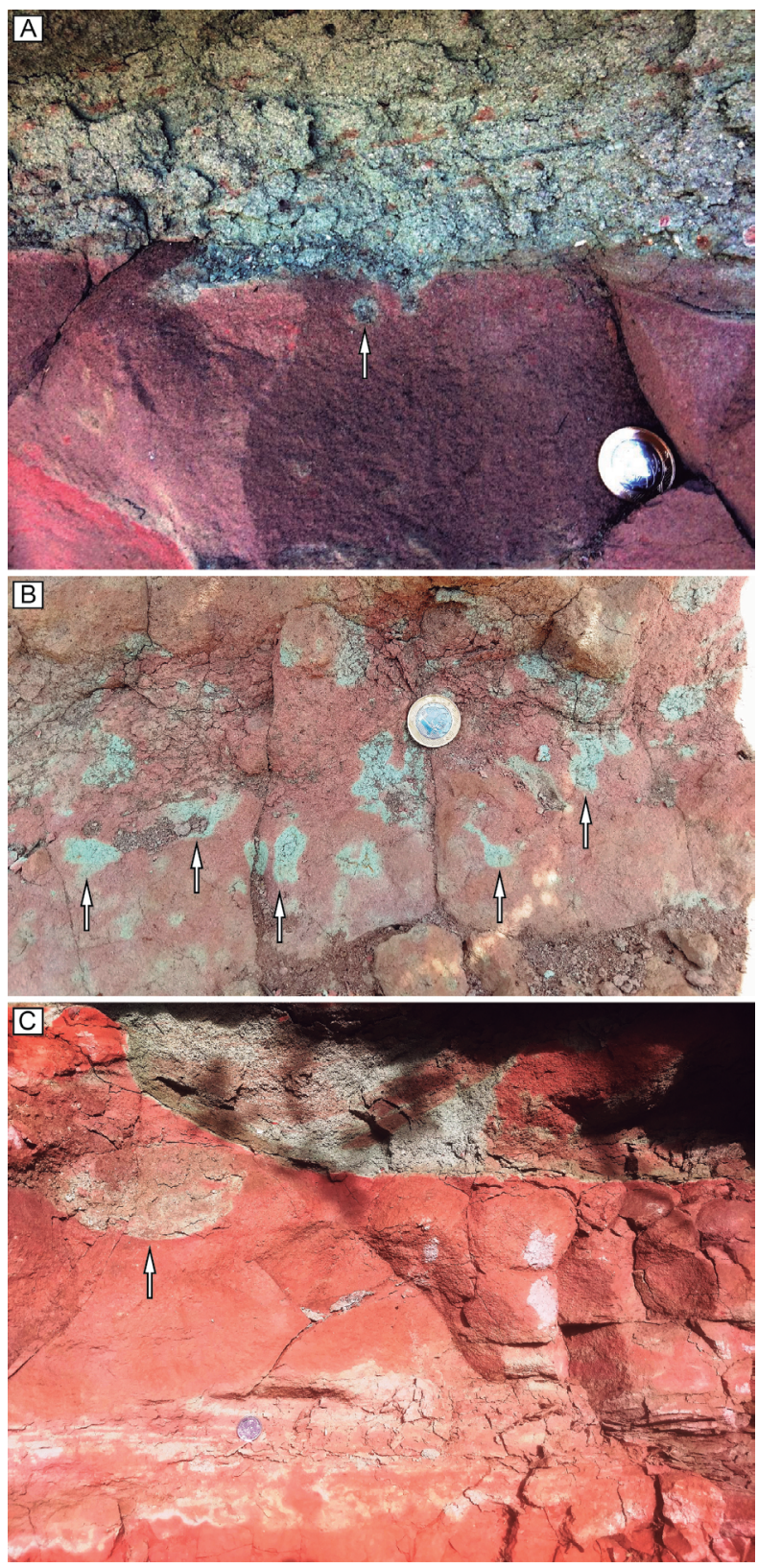

Figure 6. (A) Interface between coarse-grained lithic sandstone and fine-grained arkose showing small-scale detached pseudonodule. (B) Detached pseudonodules with irregular morphology and composed of lithic sandstone dispersed in fine-grained arkose. (C) Ball-and-pillow. Coin in A and C is $2.4 \mathrm{~cm}$ in diameter. The graphic scale in $B$ is $10 \mathrm{~cm}$ long. Black and white arrows indicate SSD structures.
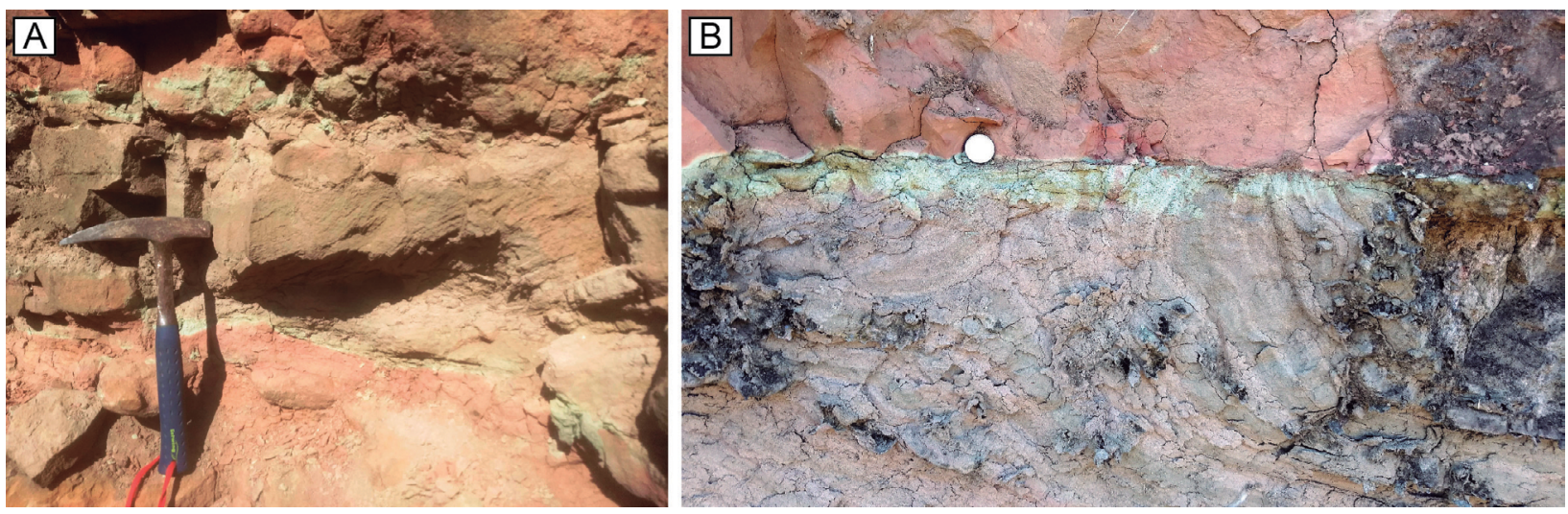

Figure 7. (A) A 30-cm thick bed of fine-grained lithic sandstone bearing small-scale antiforms and synforms. (B) Well-developed convolute laminations developed internally in the previously mentioned deformed bed. Note that the convolute laminations are confined to a single bed that was eroded by the non-deformed overlying layer. 


\section{Load structures}

\section{Load casts}

Load structures are very common features found in sandstones of the Uberaba Formation. These structures usually occur at the irregular contact between fine- to coarse-grained lithic sandstone and conglomeratic sandstone and very-fine to fine-grained arkose and mudstone. Following the nomenclature proposed by Moretti and Sabato (2007), they can be classified into large-scale load-structures (Fig. 4) and smallscale load-structures (Fig. 5).

Large-scale load structures range from 15 to $45 \mathrm{~cm}$ in length and have a concave-up semi-spherical geometry (Fig. 4). They may penetrate up to $20 \mathrm{~cm}$ into the underlying bed, and internal laminations are commonly deformed (Fig. 4A). They occur in distinct lithologies but more frequently are described in coarse-grained lithic sandstone and conglomeratic sandstone overlying very-fine grained arkose (Fig. 5A and $4 B$ ). Occasionally, such deformations are observed in fine-grained arkose overlying fine- to medium-grained lithic sandstone (Fig. 4C).

Small-scale load structures have dimensions ranging vertically between 1.0 and $6 \mathrm{~cm}$. They always appear in association with diapirs and flame structures. This structure occurs at contacts between fine- to coarse-grained lithic sandstone overlying fine-grained arkose (Fig. 5A and 5C) and contrariwise (Fig. 5B). They slightly penetrate the underlying bed and show a typical concave profile upward. These load structures lack internal lamination and resemble the "pendulous load casts" described by Owen (2003).

\section{Flame structures and diapirs}

Flame structures of the Uberaba Formation are wedgeshaped and range from few centimeters to decimeters, intruding between individual small- and large-scale load structures (Fig. 5). Most of them are formed by fine-grained arkose intruded in greenish lithic medium- to coarse-grained sandstone (Fig. 5A and 5C). Occasionally, an injection of greenish lithic medium sandstone into fine-grained arkose is also observed (Fig. 5B). These structures are morphologically related to flame and diapirs (sensu Owen 2003) and usually occur in contacts between sandstone overlying mudrock. On the other hand, flame structures of the Uberaba Formation are quite uncommon because the SSD structures are found mostly in the contacts between sandstone beds.

\section{Pseudonodules}

Pseudonodules are less frequently found than load structures, and attached pseudonodules (sensu Owen 2003) were not described in the studied outcrop. The dimensions of the detached pseudonodules range between 0.5 (Fig. 6A) and $12 \mathrm{~cm}$ (Fig. 6C). They are composed of fine- to medium-grained lithic sandstone, arranged in elliptical, rounded to irregular bodies completely disconnected from the overlying sandstone, and encapsulated by the underlying finegrained arkose (Fig 6B). The pseudonodules may penetrate up to $30 \mathrm{~cm}$ into the lower bed.

\section{Convolute lamination}

This structure is very rare in the studied outcrop and only occurs in very fine- to fine-grained lithic sandstones (Fig. 7). The maximum thickness of deformed beds may reach up to $30 \mathrm{~cm}$ (Fig. 7A). The lamination is highly contorted, resembling irregular synclines and anticlines (Fig. 7B). The intensity of deformation tends to decrease toward the base of and into undisturbed laminae (Fig. 7B).

\section{DISCUSSION}

Features such as load structures, pseudonodules, and balland-pillow are commonly interpreted to be formed in response to gravitational instability (Moretti et al. 1999, Owen 2003, Moretti and Sabato 2007). They commonly occur along the interface separating sand or sandstone from underlying mud, mudstone, or shale. However, in some cases, there is a little density contrast of these lithologies across the contact (Allen 1982, Owen 2003, Owen and Moretti 2011, Santos et al. 2012, Owen and Santos 2014). According to Owen et al. (2011), this type of deformation is dominated by vertical displacements and driven by gravitational forces coupled with a reverse density system (sensu Anketell et al. 1970). The driving forces for the origin of the small-scale load structures, pseudonodules, diapirs and flame structures in the Uberaba Formation are probably related to a reverse density system (sensu Anketell et al. 1970), generated by the density difference between fine- to coarse-grained lithic sandstone and conglomerates and fine-grained arkose and mudstone.

In the deformed intervals, the gravitationally unstable density gradient provided by fluvial bedforms allowed the denser fineto coarse-grained lithic sandstone to sink into less dense finegrained arkose and mudstone when it liquidized. Pseudonodules characterize an advanced stage in the process of deformation and displacement. With the continuity of the diapiric motion of underlying liquefied sediments, the load casts tend to be encapsulated by the low-density sediment, forming detached (or locally connected with narrow necks) pseudonodules.

Moretti and Sabato (2007) argued that water-escape structures (flame structures sensu Owen 2003) are formed by fluidization in response to an increase in the gradient of pore water pressure. According to Owen (1987), fluidization is initiated just after liquefaction, and re-sedimentation of suspended grains at lower levels take place due to an increase in pore-water pressure. Consequently, both water and sediments moved upward forming water-escape structures, sectioning and deforming the overlying bed. Thus, the presence of these structures in the Uberaba Formation (Fig. 5) can be best explained as the result of local liquefaction and fluidization of the medium- to coarse-grained lithic sands related to a water escape process. During the development of the medium- to coarse-grained load casts, the underlying finer arkose compensated its loss of volume with upward intrusions.

Convolute lamination was originally described by Kuenen (1953) as internally contorted, laminated, silt to fine-sand features bounded by upper and lower undeformed planar surfaces. Although known for a long time, the driving force mechanism for convolute laminations is still not well understood. 
Interpretations vary from current drag or bed shear, slumping, thixotropic behavior, and rapid sedimentation (see Sanders 1960, Allen 1977, Mills 1983, Neuwerth et al. 2006). In the Uberaba Formation, convolute laminations are not related to muddy beds, and the possibility of thixotropic behavior is consequently reduced. On the other hand, the deformation of primary lamination coupled with convolute folding of the sands suggests that the decrease of shear strength was induced by liquefaction.

\section{Triggering mechanism}

Liquefaction and fluidization can be induced by both endogenic and exogenic natural trigger mechanisms, including storm waves, bioturbation, floods, groundwater oscillations, overloading, rapid sedimentation, volcanic eruptions, and seismic shocks (Allen and Banks 1972, Obermeier 1996, Owen et al. 2011). Field evidence shows that most of the described SSD structures in fine- to coarse-grained lithic sandstone and finegrained sandy rocks from the Uberaba Formation were induced by liquefaction-fluidization processes. Prior to considering an exogenic trigger, it is fundamental to exclude the influence of endogenic sedimentary processes in the unconsolidated sediments (Moretti 2000, Moretti and Sabato 2007). The action of storm waves can be easily excluded due to the exclusively continental (fluvial) depositional setting interpreted for the Uberaba Formation (Batezelli et al. 2019). The semi-arid to arid climate inferred for this part of South America during the Late Cretaceous (Batezelli et al. 2019), similarly precludes the possibility of liquefaction and fluidization promoted by unequal loading associated with glaciers or ice caps. Likewise, there is no evidence of associated bioturbation, such as invertebrate burrows and vertebrate tracks, capable of generating localized liquefaction and fluidization. Evidence of slumps and gravitational slides are also absent and can be discarded.

Thus, considering this context, a plausible trigger mechanism could be associated with sediment loading related to rapid deposition (in terms of Owen 1996). The preserved unstable minerals (i.e., pyroxene, amphibole, and volcanic clasts), low rounded grains, and lack of syndepositional muds within the framework of the terrigenous rocks from the Uberaba Formation point to deposition under high energy conditions (Batezelli 2003). The occurrence of matrix-supported massive conglomerate and conglomeratic sandstone also reinforce the rapid sedimentation, probably in fluvial channels, by inertial bedflows. Moretti et al. (2001) showed that rapid sedimentation is a common trigger mechanism for liquefaction in sandon-sand and sand-on-clay systems. According to this model, the rapid deposition of sand could induce liquefaction in great depths below the sediment-water interface at the same time as the excess of pore-water pressure remains very high in the underlying sediments for hours, causing subsequent expulsion of fluid. In this way, the small-scale load structures formed by lithic sandstone and conglomeratic sandstone overlying arkose and mudstone (Fig. 5) can be interpreted as the product of the sudden deposition of decimeter-thick beds of conglomerate and conglomeratic sandstone in fluvial channels promoting a rapid increase in interstitial pore-water pressure in the underlying fine-grained arkose and mudstone (Moretti and Sabato 2007).
On the other hand, the small and large-scale load structures composed of fine-grained arkose overlying medium- to coarse-grained lithic sandstone are not necessarily related to beds deposited by punctual and energetic processes. Thus, it is necessary to propose distinct exogenic triggers for the generation of SSD structures, as deformation induced by tsunami waves, impact of extraterrestrial bodies, and seismic shaking (Obermeier 1996, Owen et al. 2011). The first two can be discarded due to the nonexistence of impact craters with Campanian age in the Bauru Basin and the exclusively continental deposition inferred for the Uberaba Formation. Thus, excluding all aforementioned possibilities, we conclude that seismic shaking must have been induced the formation of the aforementioned SSD structures described in the Uberaba Formation. In this way, the horizons bearing SSD structures could be considered as true seismites (sensu Mills 1983, Obermeier 1996, Moretti 2000, Ettensohn et al. 2002, Røe and Hermansen 2006, Owen et al. 2011, Santos et al. 2012, Moretti et al. 2014, Rossetti et al. 2017). Evidence that supports this hypothesis are:

- wide lateral continuity of deformed layers (c.f. Santos et al. 2012, Røe and Hermansen 2006, Moretti et al. 2014) for hundreds of meters to kilometers. It is important to note that this study was focused on one single outcrop, but tens of other were visited in the surroundings and presented deformational structures similar to those detailed here;

- presence of deformed layers bounded by undeformed beds (e.g., Ettensohn et al. 2002, Santos et al. 2012, Moretti et al. 2014);

- the deformed beds are restricted to a unique stratigraphic interval (the intermediate part of the Uberaba Formation);

- recurrence of deformed beds through time (Santos et al. 2012, Moretti et al. 2014, Rossetti 1999);

- compatible morphology of the described structures and seismites;

- reactivation of regional structures (Riccomini et al. 2005) coeval with alkaline explosive magmatism (Campos and Dardenne 1997).

\section{Searching for Late Cretaceous intraplate earthquakes}

Based on the study of liquefaction-induced features of distinct Holocene geological settings from the USA, Obermeier (1996) demonstrated that SSD structures can be a powerful tool to estimate the recurrence interval and magnitude of moderate to great (sensu Richter magnitude scale) earthquakes. The epicentral distance (radius) to the farthest liquefaction feature $(\mathrm{km})$ can be correlated with the earthquake moment magnitude (M) for both shallow and deep-focus earthquakes. Earthquakes with at least $M>5$ are required to generate liquefaction-induced features (Obermeier 1996). The analysis of the tectono-magmatic context of the Alto Paranaíba region during the Late Cretaceous reveals a potential tectonic active area for the origin of paleo-earthquake events related to the origin of the Uberaba Formation SSD structures.

During the Late Cretaceous, the Bauru Basin was infilled by 2300 meters of siliciclastic sediments deposited in exclusively continental settings (Fernandes and Coimbra 1994, 
Milani and De Wit 2008, Batezelli and Ladeira 2016, Basilici et al. 2016, Dal'Bó et al. 2018). The sedimentation of the Uberaba Formation occurred during the Campanian Age, between 83.6 and 72.1 Ma (Huene 1939, Santucci and Bertini 2001, Tamrat et al. 2002), strongly coinciding with the ages of fault reactivations along the Neoproterozoic basement and the alkaline magmatism in the Alto Paranaiba High and the Rondonópolis Anteclise. Thus, considering that the uplift along basement discontinuities, alkaline plutono-volcanic activity, and deposition of the Uberaba Formation are coeval, we conclude that the liquefaction and fluidization responsible for the formation of the studied SSD structures were most probably triggered by Late Cretaceous seismicity. The distance between the study area and the Poxoreu Igneous Province is about $850 \mathrm{~km}$; thus we discard this setting as the main source of the paleo-earthquakes that generated the SSD structures. On the other hand, due to their proximity to the study area, the uplift of the Alto Paranaíba High and/or magmatism in the Minas-Goiás Alkaline Province are the most promising candidates as seismicity sources. Despite the reduced number of data presented in this study, considering the magnitude-bound method proposed by Obermeier (1996), it is possible to estimate that earthquakes that produced the SSD structures had a moment of magnitudes $(\mathrm{M})$ greater than 5.0 (the minimum required to generate liquefaction-induced features).

\section{CONCLUDING REMARKS}

The Uberaba Formation of the intracratonic Bauru Basin is interpreted as deposited in a large alluvial braided river system during the Late Cretaceous. At that time, the northeastern border of the basin was affected by the uplift of the Alto Paranaíba High and plutono-volcanic magmatism of the Minas-Goiás Alkaline Province. At least three distinct surfaces along the contact between lithic sandstone and conglomerate with fine-grained arkose and mudstone contain widespread soft-sediment deformations interbedded with undeformed strata. The SSD structures described here occur in the intermediate part of the Uberaba Formation and can be classified into two main groups: load structures (load casts, flame structures, and pseudonodules), and convolute laminations.
These deformations are attributed to liquefaction-fluidization processes. Driving forces for the generation of small-scale load structures are associated with gravitationally unstable density gradients triggered by overloading (sensu Moretti and Sabato 2007). Gravitational forces, coupled with a reverse density system, are also the driving-force system for large-scale load structures. However, in this case, liquefaction and fluidization were produced by seismic shocks. Pseudonodules are associated with gravitational instabilities related to density differences. Flame structures are associated with fluidization and injection of sands into surrounding load structures. As convolute laminations within the Uberaba Formation are clearly confined to deformed beds that were eroded by non-deformed overlying bed, this structure is most probably related to earthquakes.

In sum, the studied intervals bearing large-scale load structures and convolute laminations can be classified as seismites (sensu Mills 1983, Obermeier 1996, Moretti 2000, Ettensohn et al. 2002, Røe and Hermansen 2006, Owen et al. 2011, Santos et al. 2012, Moretti et al. 2014, Rossetti et al. 2017). The Late Cretaceous reactivation of the Precambrian basement (i.e., Brasília Fold Belt), which led to the uplift of the Alto Paranaíba High, and the magmatism of the MinasGoiás Alkaline Province, were the most probable sources of the seismicity. Estimated magnitudes of the paleo-earthquakes that affected the study area are surely bigger than 5.0 (M). The seismites previously described in the Caiuá Group (Fernandes et al. 2007) and the recognition of new occurrences in the studied section reinforces the influence of tectonic activity during the deposition of the Late Cretaceous Bauru Basin. Finally, the study of the Uberaba Formation SSD structures provides an excellent opportunity to investigate the relationships between reactivation of regional intraplate discontinuities, coeval magmatism, sedimentary processes, and their influence in the continental deposition during the Late Cretaceous of the central-southeastern South American Platform.

\section{ACKNOWLEDGMENTS}

L.V.W. is fellow of CNPq. L.A thanks Graziela Guadagnin for help during fieldwork.

\section{ARTICLE INFORMATION}

Manuscript ID: 20190100. Received on: 09/27/2019. Approved on: 03/30/2020.

Author L. A. wrote the first draft of the manuscript and prepared Figures 1 to 7 . Author L. W. improved the manuscript through corrections and suggestions. Author M. G. M. S. provided advisorship regarding soft-sediment deformation structures. Author M. V. helped during fieldworks. Competing interests: The authors declare no competing interests.

\section{REFERENCES}

Alfaro P., Moretti M., Soria J.M. 1997. Soft-sediment deformation structures induced by earthquakes (seismites) in pliocene lacustrine deposits (Guadix-Baza Basin, Central Betic Cordillera). Eclogae Geologicae Helvetiae, 90:531-540.

Allen J.R.L. 1977. The possible mechanics of convolute lamination in graded sand beds. Journal of the Geological Society, 134:19-31. https://doi. org/10.1144/gsigs.134.1.0019

Allen J.R.L. 1982. Sedimentary Structures: Their Character and Physical Basis. Amsterdam, Elsevier, 663 p. v. 2.
Allen J.R.L. 1986. Earthquake magnitude-frequency, epicentral distance, and soft sediment deformation in sedimentary basins. Sedimentary Geology, 46(1-2):67-75. https://doi.org/10.1016/0037-0738(86)90006-0

Allen J.R.L., Banks N.L. 1972. An interpretation and analysis of recumbentfolded deformed cross-bedding. Sedimentology, 19(3-4):257-283. https:// doi.org/10.1111/j.1365-3091.1972.tb00024.x

Almeida F.F.M. 1983. Relações tectônicas das rochas alcalinas mesozóicas da região meridional da Plataforma Sul-Americana. Revista Brasileira de Geociências, 13(3):139-158. 
Amaral G., Bushee J., Cordani U.G., Kawashita K., Reynolds J.H. 1967. Potassium-argon ages of alkaline rocks from southern Brazil. Geochimica et Cosmochimica Acta, 31(2):117-142. https://doi.org/10.1016/ S0016-7037(67)80041-3

Anketell J.M., Cegla J., Dzulynski S. 1970. On the deformational structures in systems with reversed density gradients. Annales de la Société Geologique de Pologne, 40:3-30.

Basilici G., Dal'Bó P.F.F. 2010. Anatomy and controlling factors of a Late Cretaceous aeolian sand sheet: the Marília and the Adamantina formations, NW Bauru Basin, Brazil. Sedimentary Geology, 226(1-4):71-93. https://doi. org/10.1016/j.sedgeo.2010.02.010

Basilici G., Dal'Bó P.F., Oliveira E.F. 2016. Distribution of palaeosols and deposits in the temporal evolution of a semiarid fluvial distributary system (Bauru Group, Upper Cretaceous, SE Brazil). Sedimentary Geology, 341:245-264. https://doi.org/10.1016/j.sedgeo.2016.04.014

Batezelli A. 2003. Análise da sedimentação cretácea no Triângulo Mineiro esua correlação com áreas adjacentes. 183f. Thesis, Instituto de Geociências e Ciências Exatas, Universidade Estadual Paulista “Júlio de Mesquita Filho”, Rio Claro.

Batezelli A. 2015. Continental systems tracts of the Brazilian Cretaceous Bauru Basin and their relationship with the tectonic and climatic evolution of South America. Basin Research, 29(Supl. 1):1-25. https://doi.org/10.1111/ bre. 12128

Batezelli A., Gomes N.S., Perinotto J.A.D.J. 2016. Petrografia e evolução diagenética dos arenitos da porção norte e nordeste da Bacia Bauru (Cretáceo Superior). Revista Brasileira de Geociências, 35(3):311-322. https://doi.org/10.25249/0375-7536.2005353311322

Batezelli A., Ladeira F.S.B. 2016. Stratigraphic framework and evolution of the Cretaceous continental sequences of the Bauru, Sanfranciscana, and Parecis basins, Brazil. Journal of South American Earth Sciences, 65:1-24. https://doi.org/10.1016/j.jsames.2015.11.005

Batezelli A., Ladeira F.S.B., Nascimento D.L., Silva M.L. 2019. Facies and palaeosol analysis in a progradational distributive fluvial system from the Campanian-Maastrichtian Bauru Group, Brazil. Sedimentology, 66(2):699735. https://doi.org/10.1111/sed.12507

Campos J.E.G., Dardenne M.A. 1997. Estratigrafia e sedimentação da Bacia Sanfranciscana: uma revisão. Revista Brasileira de Geociências, 27(3):269-282

Coimbra A.M., Fernandes L.A. 1995. Paleogeografia e Considerações Paleoecológicas Sobre a Bacia Bauru (Cretáceo Superior do Brasil). In: Congreso Argentino de Paleontologia y Bioestratigrafia, 4., 1995. Annals...

Costa M.T., Sad J.H.G. 1968. O Cretáceo em Minas Gerais. In: Congresso Brasileiro de Geologia, 22., Belo Horizonte. Anais..., p. 23-36.

Dal’Bó P.F., Soares M.V.T., Basilici G., Rodrigues A.G., Menezes M.N. 2018. Spatial variations in distributive fluvial system architecture of the Upper Cretaceous Marília Formation, SE Brazil. Geological Society, London, Special Publications, 488:97-118. https://doi.org/10.1144/SP488.6

Ettensohn F.R., Rast N., Brett C.E. 2002. Ancient seismites. Geological Society of America, Special Paper, 359 p.

Fernandes L.A., Coimbra. A.M. 1994. O Grupo Caiuá (Ks): revisão estratigráfica e contexto deposicional. Revista Brasileira de Geociências, 24(3):164-176

Fernandes L.A., Coimbra A.M. 2017. Revisão estratigráfica da parte oriental da Bacia Bauru (Neocretáceo). Revista Brasileira de Geociências, 30(4):717-728

Fernandes L.A., de Castro A.B., Basilici G. 2007. Seismites in continental sand sea deposits of the Late Cretaceous Caiuá Desert, Bauru Basin, Brazil. Sedimentary Geology, 199(1-2):51-64. https://doi.org/10.1016/j. sedgeo.2005.12.030

Fernandes L.A., Giannini P.C., Góes A.M. 2003. Araçatuba Formation: palustrine deposits from the initial sedimentation phase of the Bauru Basin. Anais da Academia Brasileira de Ciências, 75(2):173-187. https://doi. org/10.1590/S0001-37652003000200006

Ferreira Jr. P.D., Gomes N.S. 1999. Petrografia e diagênese da Formação Uberaba, Cretáceo Superior da Bacia Do Paraná no Triângulo Mineiro. Revista Brasileira de Geociências, 29(2):163-172.
Gibert L., Alfaro P., García-Tortosa F.J., Scott G. 2011. Superposed deformed beds produced by single earthquakes (Tecopa Basin, California): insights into paleoseismology. Sedimentary Geology, 235(3-4):148-159. https://doi. org/10.1016/j.sedgeo.2010.08.003

Gibson S.A., Thompson R.N., Leonardos O.H., Dickin A.P., Mitchell J.G. 1995. The late cretaceous Impact of the trindade mantle plume: evidence from large volume, Mafic, Potassic Magmatism in SE Brazil. Journal of Petrology, 36(1):189-229. https://doi.org/10.1093/petrology/36.1.189

Gibson S.A., Thompson R.N., Leonardos O.H., Turner S., Mitchell J.G., Dickin A.P. 1994. The Serra do Bueno potassic diatreme: a possible hypabissal equivalent of the ultramafic potassic volcanics in the Cretaceous Alto Paranaíba Igneous Province, SE Brazil. Mineralogical Magazine, 58(392):357-373. https://doi.org/10.1180/minmag.1994.058.392.02

Gibson S.A., Thompson R.N., Weska R.K., Dickin A.P., Leonardos O.H. 1997. Late Cretaceous rift-related upwelling and melting of the Trindade starting mantle plume head beneath western Brazil. Contributions to Mineralogy and Petrology, 126:303-314. https://doi.org/10.1007/s004100050252

Gomes C.B., Ruberti E., Morbidelli L. 1990. Carbonatite complexes from Brazil: a review. Journal of South American Earth Sciences, 3(1):51-63. https://doi.org/10.1016/0895-9811(90)90017-U

Hasui Y. 1968. A Formação Uberaba. In: Congresso Brasileiro de Geologia, 22, Belo Horizonte. Anais... Belo Horizonte, SBG, p. 167-179.

Hasui Y., Cordani U.G. 1968. Idades potássio-argônio de rochas eruptivas mesozóicas do leste mineiro e sul de Goiás. In: Congresso Brasileiro de Geologia, 22., Belo Horizonte. Anais ..., p. 139-143.

Hasui Y., Haralyi N.L.E. 1991. Aspectos lito-estruturais e geofísicos do soerguimento do Alto Paranaíba. Geociências, 10(1):57-77.

Hasui Y., Sadowski G.R., Suguio K., Fuck G.F. 1975. The Phanerozoic evolution of the Western Minas Gerais State. Anais da Academia Brasileira de Ciências, 47(3-4):431-438.

Huene F. Von. 1939. Carta de F. von Huene ao Dr. Euzébio de Oliveira. Mineração e Metalurgia, 4(22): 190.

Hussak E. 1906. Rocha Tufácea de Uberaba, Rico em Perowiskita. Zeitschrift für Prakitische Geologie, 16:322-324.

Junqueira-Brod T.C., Roig H.L., Gaspar J.C., Brod J.A., Meneses P.R. 2002. A Província Alcalina de Goiás e a extensão do seu vulcanismo kamafugítico. Brazilian Journal of Geology, 32(4):559-566.

Kuenen P.H. 1953. Graded bedding, with observations on Lower Paleozoic rocks of Britain. Amsterdam, North-Holland Pub. Co.

Leonardos O.H., Ulbrich M.C.N., Gaspar J.C. 1991. The Mata da Corda volcanic rocks. In: International Kimberlite Conference, 5., Araxá. Field Guide Book..., p. 17-24.

Lowe D.R. 1975. Water escape structures in coarse-grained sediments Sedimentology, 22(2):157-204.https://doi.org/10.1111/j.1365-3091.1975. tb00290.x

Maisey J.G. 2000. Continental break up and the distribution of fishes of Western Gondwana during the Early Cretaceous. Cretaceous Research, 21(2-3):281-314. https://doi.org/10.1006/cres.1999.0195

Maltman A.J., Hubbard B., Hambrey M.J. (Eds.). 2000. Deformation of Glacial Materials. Geological Society, London, Special Publications, 176:1-9. https://doi.org/10.1144/GSL.SP.2000.176.01.01

Menegazzo M.C., Catuneanu O., Chang H.K. 2016. The South American retroarc foreland system: The development of the Bauru Basin in the backbulge province. Marine and Petroleum Geology, 73:131-156. https://doi. org/10.1016/j.marpetgeo.2016.02.027

Miall A.D. 1996. The Geology of Fluvial Deposits: Sedimentary Facies, Basin Analysis and Petroleum Geology. Berlin, Springer.

Miall A.D. 2010. Alluvial deposits. In: James N.P. and Dalrymple R.W. (Eds.) Facies Models 4. Canada, The Geological Association of Canada, p. 105-138.

Milani E.J., De Wit M.J. 2008. Correlations between the classic Paraná and Cape - Karoo sequences of South America and southern Africa and their basin infills flanking the Gondwanides: du Toit revisited. In: Pankhurst R.J., Trouw R.A.J., Brito Neves B.B., De Wit M.J. (Eds.). West Gondwana: Pre-Cenozoic Correlations Across the South Atlantic Region, 294. Geological Society, Special Publications, p. 319-342. 
Mills P.C. 1983. Genesis and diagnostic value of soft-sediment deformation structures - a review. Sedimentary Geology, 35(2):83-104. https://doi. org/10.1016/0037-0738(83)90046-5

Moretti M. 2000. Soft-sediment deformation structures interpreted as seismites in middle-late Pleistocene aeolian deposits (Apulian foreland, southern Italy). Sedimentary Geology, 135(1-4):167-179. https://doi. org/10.1016/S0037-0738(00)00070-1

Moretti M., Alfaro P., Caselles O., Canas J.A. 1999. Modelling seismites with a digital shaking table. Tectonophysics, 304(4):369-383. https://doi. org/10.1016/S0040-1951(98)00289-3

Moretti M., Sabato L. 2007. Recognition of trigger mechanisms for soft-sediment deformation in the Pleistocene lacustrine deposits of the Sant'Arcangelo Basin (southern Italy): seismic shock vs. overloading. Sedimentary Geology, 196(1-4):31-45. https://doi.org/10.1016/j. sedgeo.2006.05.012

Moretti M., Soria J.M., Alfaro P., Walsh N. 2001. Asymmetrical softsediment deformation structures triggered by rapid sedimentation in turbiditic deposits (Late Miocene, Guadix Basin, Southern Spain). Facies, 44(1):283-294. https://doi.org/10.1007/BF02668179

Moretti M., van Loon A.T., Liu M., Wang Y. 2014. Restrictions to the application of 'diagnostic'criteria for recognizing ancient seismites. Journal of Palaeogeography, 3(2):162-173. https://doi.org/10.3724/ SP.J.1261.2014.00050

Moura-Lima E., Bezerra F.H.R., Lima-Filho F.P., de Castro D.L., Sousa M.O.L., Fonseca V.P., Aquino M.R. 2011. 3-D geometry and luminescence chronology of Quaternary soft sediment deformation structures in gravels, northeastern Brazil. Sedimentary Geology, 235(3-4):160-171. https://doi. org/10.1016/j.sedgeo.2010.09.016

Neuwerth R., Suter F., Guzman C.A., Gorin G.E. 2006. Soft-sediment deformation in a tectonically active area: The Plio-Pleistocene Zarzal Formation in the Cauca Valley (Western Colombia). Sedimentary Geology, 186(1-2):67-88. https://doi.org/10.1016/j.sedgeo.2005.10.009

Nichols R.J., Sparks R.S.J., Wilson C.J.N. 1994. Experimental studies of the fluidization of layered sediments and the formation of fluid escape structures. Sedimentology, 41(2):233-253.https://doi.org/10.1111/j.1365-3091.1994. tb01403. $x$

Obermeier S.F. 1996. Use of liquefaction-induced features for paleoseismic analysis - an overview of how seismic liquefaction features can be distinguished from other features and how their regional distribution and properties of source sediment can be used to infer the location and strength of Holocene paleo-earthquakes. Engineering Geology, 44(1-4):1-76. https:// doi.org/10.1016/S0013-7952(96)00040-3

Oliveira I.W.B., Sachs L.L.B., Silva V.A., Batista I.H. 2004. Folha SE.23-Belo Horizonte. In: Schobbenhaus C., Gonçalves J.H., Santos J.O.S., Abram M.B., Leão Neto R., Matos G.M.M., Vidotti R.M., Ramos M.A.B., Jesus J.D.A. (Eds.). Carta geológica do Brasil ao millionésimo: Sistema de Informações Geográficas SIG e 46 folhas na escala 1:1.000.000. Brasília: CPRM. 41 CD-ROM Pack.

Owen G. 1987. Deformation processes in unconsolidated sands. In: Jones M.E. and Preston R.M.F. (Eds.). Deformation of Sediments and Sedimentary Rocks. Geological Society Special Publication, 29:11-24.

Owen G. 1996. Experimental soft-sediment deformation structures formed by the liquefaction of unconsolidated sands and some ancient examples. Sedimentology, 43(2):279-293. https://doi. org/10.1046/j.1365-3091.1996.d01-5.x

Owen G. 2003. Load structures: gravity-driven sediment mobilization in the shallow subsurface. In: Van Rensbergen P., Hillis R.R., Maltman A.J., Morley C.K. (Eds.), Subsurface Sediment Mobilization. Geological Society of London, Special Publications 216:21-34.

Owen G., Moretti M. 2011. Identifying triggers for liquefaction-induced softsediment deformation in sands. Sedimentary Geology, 235(3-4):141-147. https://doi.org/10.1016/j.sedgeo.2010.10.003

Owen G., Moretti M., Alfaro P. 2011. Recognising triggers for softsediment deformation: current understanding and future directions. Sedimentary Geology, 235(3-4):133-140. https://doi.org/10.1016/j. sedgeo.2010.12.010

Owen G., Santos M.G.M. 2014. Soft-sediment deformation in a prevegetation river system: the Neoproterozoic Torridonian of NW Scotland
Proceedings of the Geologists' Association, 125(5-6):511-523. https://doi. org/10.1016/j.pgeola.2014.08.005

Quintão D.A., Caxito F.A., Karfunkel J., Vieira F.R., Seer H.J., Moraes L.C., Ribeiro L.C.B., Pedrosa-Soares A.C. 2017. Geochemistry and sedimentary provenance of the Upper Cretaceous Uberaba Formation (Southeastern Triângulo Mineiro, MG, Brazil). Brazilian Journal of Geology, 47 (2):159-182. https://doi.org/10.1590/2317-4889201720170032

Riccomini C., Velásquez V.F., Gomes C.B. 2005. Tectonic controls of the mesozoic and cenozoic alkaline magmatism in central-southeastern Brazilian Platform. In: Comin-Chiaramonti P., Gomes C.B. (Eds.). Mesozoic to cenozoic alkaline magmatism in the Brazilian Platform. São Paulo: EduspFapesp, p. 31-56.

Røe S.L. and Hermansen M. 2006. New aspects of deformed cross-strata in fluvial sandstones: Examples from Neoproterozoic formations in northern Norway. Sedimentary Geology, 186(3-4):283-293. https://doi. org/10.1016/j.sedgeo.2005.11.023

Rosetti D.F. 1999. Soft sediment deformation structures in Late Albian to Cenomanian deposits, Sao Luis Basin, northern Brazil: evidence for paleoseismicity. Sedimentology, 46(6):1065-1081. https://doi. org/10.1046/j.1365-3091.1999.00265.x

Rossetti D.F., Alves F.C., Valeriano M.M. 2017. A tectonically-triggered late Holocene seismite in the southern Amazonian lowlands, Brazil. Sedimentary Geology, 358:70-83. https://doi.org/10.1016/j.sedgeo.2017.07.003

Rossetti D.F., Bezerra F.H.R., Góes A.M., Neves B.B.B. 2011. Sediment deformation in Miocene and post-Miocene strata, Northeastern Brazil: evidence for paleoseismicity in a passive margin. Sedimentary Geology, 235(3-4):172-187. https://doi.org/10.1016/j.sedgeo.2010.02.005

Rust B.R. 1968. Deformed cross-bedding in Tertiary-Cretaceous sandstone, Arctic Canada. Journal of Sedimentary Research, 38(1):87-91. https://doi. org/10.1306/74D718E3-2B21-11D7-8648000102C1865D

Sad G.J.H. 1970. Complexos silicocarbonatíticos da região do Alto Paranaíba, Brasil Meridional. In: Congresso Brasileiro de Geologia, 24., Brasília. Resumo das conferências e comunicações..., SBG, p. 16-19.

Sanders J.E. 1960. Origin of convoluted laminae. Geological Magazine, 97(5):409-421. https://doi.org/10.1017/S0016756800061768

Santos M.G.M., Almeida R.P., Mountney N.P., Fragoso-Cesar A.R.S. 2012. Seismites as a tool in the palaeoenvironmental reconstruction of fluvial deposits: the Cambrian Guarda Velha Formation, southern Brazil. Sedimentary Geology, 277-278:52-60. https://doi.org/10.1016/j. sedgeo.2012.07.006

Santucci R.M., Bertini R.J. 2001. Distribuição Paleogeográfica e Biocronológica dos Titanossauros (Saurish, Sauropoda) do Grupo Bauru, Cretáceo Superior do Sudeste Brasileiro. Revista Brasileira de Geociências, 31(3):307-315.

Seer H., Moraes L.C. 2017. Mapa Geológico da Folha Uberaba, escala 1:100.000. Belo Horizonte: Projeto de Mapeamento Geológico CODEMIG/UFMG.

Seilacher A. 1969. Fault-graded beds interpreted as seismites. Sedimentology, 13(1-2):155-159. https://doi.org/10.1111/j.1365-3091.1969.tb01125.x

Seilacher A. 1984. Sedimentary structures tentatively attributed to seismic events. Marine Geology, 55(1-2):1-12. https://doi. org/10.1016/0025-3227(84)90129-4

Seilacher A. 1991. Events and their signatures: an overview. Cycles and Events in Stratigraphy. Berlin, Springer-Verlag

Shiki T., Cita M.B., Gorsline D.S. (Eds.). 2000. Sedimentary Features of Seismites, Seismo-Turbidites and Tsunamiites. Sedimentary Geology, 135(1-4):VIII-IX. https://doi.org/10.1016/S0037-0738(00)00058-0

Silva R.B., Etchebehere M.L.C., Saad A.R. 1994. Groundwater calcretes: uma interpretação alternativa para os calcários da Formação Marília no Triângulo Mineiro. In: Simpósio sobre o Cretáceo do Brasil, 3., 1994. Boletim..., p. 85-89.

Sonoki I.K., Garda G.M. 1988. Idades K-Ar de rochas alcalinas do Brasil meridional e Paraguai oriental: compilação e adaptação às novas constantes de decaimento. Boletim do Instituto de Geociências da USP, Série Científica, 19:63-85. https://doi.org/10.11606/issn.2316-8986.v19i0p63-85 
Braz. J. Geol. (2020), 50(1): e20190100

Souza M.Z.A. 1997. Petrologia e geoquímica do complexo ancalino Ponta do Morro, MT. Ph.D. Thesis, University of São Paulo, São Paulo, 168 p.

Suguio K., Barcelos J.H. 1983. Significado paleoambiental de estrutura "boudinóide" e outras feições presentes na seção tipo da Formação Santo Anastácio do Grupo Bauru, Estado de São Paulo. Boletim do Instituto de Geociências da USP, Série Científica, 14:49-54.

Tamrat E., Ernesto M., Fulfaro V.J., Saad A.R., Batezelli A., Oliveira A.F. 2002. Magnetoestratigrafia das formações Uberaba e Marília (Grupo Bauru) no Triângulo Mineiro (MG). In: Simpósio sobre o Cretáceo do Brasil, 6., e Simpósio sobre el Creácico de América del Sur, 2., São Pedro. Boletim... São Pedro, p. 323-327.
Thiede D.S., Vasconcelos P.M. 2010. Paraná flood basalts: rapid extrusion hypothesis confirmed by new ${ }^{40} \mathrm{Ar} /{ }^{39} \mathrm{Ar}$ results. Geology, 38(8):747-750. https://doi.org/10.1130/G30919.1

Van Rensbergen P., Hillis R.R., Maltman A.J., Morley C.K. 2003. Subsurface Sediment Mobilization. London: Geological Society, Special Publications, v. 216.

van Loon A.J. 2009. Soft-sediment deformation structures in siliciclastic sediments: an overview. Geologos, 15(1):3-55.

VanDecar J.C., James D.E., Assumpção M. 1995. Seismic evidence for a fossil mantle plume beneath South America and implications for plate driving forces. Nature, 378:25-31. https://doi.org/10.1038/378025a0 